\title{
Brown Bead of Broccoli. II. Relationships of the Physiological Disorder with Nutritional and Meteorological Variables
}

\author{
Sylvie Jenni ${ }^{1}$ \\ Agriculture and Agri-Food Canada, Horticultural Research and Development \\ Centre, Saint-Jean-sur-Richelieu, QC, J3B 3E6, Canada
}

Pierre Dutilleul $^{2}$ and Stephen Yamasaki ${ }^{3}$

Macdonald Campus of McGill University, 21111 Lakeshore Road, SainteAnne-de-Bellevue, QC, H9X 3V9, Canada

\author{
Nicolas Tremblay ${ }^{4}$ \\ Agriculture and Agri-Food Canada, Horticultural Research and Development \\ Centre, Saint-Jean-sur-Richelieu, QC, J3B 3E6, Canada
}

Additional index words. brown bud, Brassica oleracea, water, temperature, nitrogen, calcium, transplant, direct seed

\begin{abstract}
In order to investigate their relationships with brown bead, a data set composed of 48 variables characterizing the developmental rate, climate, and nutrients in the soil and in the tissues of heads of broccoli (Brassica oleracea $L$., Italica group) was collected from 328 plots (41 experimental fields over 3 years $\times 4 \mathrm{~N}$ fertilization levels $\times 2$ blocks). The four $\mathrm{N}$ treatments were 85-0-0,85-54-0, 85-54-54, and 85-54-108, the first number indicating the $\mathbf{N}$ level $\left(\mathrm{kg}^{\circ} \mathrm{ha}^{-1}\right)$ applied before planting; the second, $\mathrm{N}$ level applied 5 weeks after planting; and the last, $N$ level applied 7 weeks after planting. Broccoli plants were either direct-seeded ( 26 experimental fields) or transplanted (15 experimental fields). Whether direct-seeded or transplanted, fast-developing broccoli plants showed a lower incidence of brown bead. More particularly, heads of transplanted broccoli plants experiencing warmer temperatures had a lower brown bead incidence and severity. A regular supply of water decreased the incidence and severity of the physiological disorder in both directseeded and transplanted broccoli plants. Low levels of $\mathrm{Ca}$ and high levels of $\mathrm{Mg}$ and $\mathrm{K}$ in mature broccoli head tissues were associated with a higher incidence of brown bead. Multiple-regression models were developed to predict the percentage of broccoli heads with brown bead for direct-seeded plants $\left(R^{2}=0.76 ; n=104\right)$, and for transplanted plants $\left(R^{2}=0.69 ; n=44\right)$. For direct-seeded broccoli, solar radiation between the button stage (head diameter of $2.5 \mathrm{~cm}$ ) and maturity (head diameter of $10 \mathrm{~cm}$ ), as well as soil and tissue Mg content, were among the first variables to enter the regression models. In general, more solar radiation and less precipitation translated into more heads showing brown bead symptoms. For transplanted broccoli plants, the minimum temperature from the button stage to maturity was a key variable in the prediction of the percentage of heads with brown bead and the corresponding index of severity.
\end{abstract}

Brown bead is a physiological disorder that was first observed in broccoli (Brassica oleracea L., Italica group) in the 1970s during

Received for publication 25 Oct. 2000. Accepted for publication 14 Apr. 2001. Agriculture and AgriFood Canada, Saint-Jean-sur-Richelieu (Que.), Contribution no. 335/2001.03.02R. The authors would like to thank François Cousineau of Les Fermes Paul Cousineau et Fils, and the Matching Investment Initiative (MII) Program of Agriculture and AgriFood Canada for their financial support, as well as Julie Nichols, Nathalie Leboeuf, Jean-François Dubuc, and Gaston Mercier for their technical assistance. ${ }^{1}$ Researcher; to whom reprint requests should be addressed. E-mail address: jennis@em.agr.ca

${ }^{2}$ Associate Professor, Statistician, Plant Science Dept. ${ }^{3}$ Postdoctoral Fellow; present address: Dept. des sciences biologiques, Université du Québec à Montréal, C.P. 8888, Succ. Centre-ville, Montréal, Qué, H3C 3P8, Canada.

${ }^{4}$ Researcher. a production boom in California. Subsequently, brown bead was responsible for the abandonment of substantial acreage and loss of product quality in this state (Steta, 1987). Restriction of the production to areas and periods more suitable for the climatic requirements of broccoli as well as use of more resistant varieties considerably reduced the occurrence of the disorder.

Broccoli is one of Canada's 10 major imported fresh vegetables, with 76,000 $\mathrm{t}$ of broccoli imported in 1998 (Agriculture and AgriFood Canada, 1999). In 1999, 19,000 t of broccoli were grown on 1500 ha of land in the province of Quebec, which represented $57 \%$ of the Canadian production. Presently, brown bead is responsible for up to one-third of the field rejects. Up to now, little work has been done on understanding the causes leading to brown bead. Under field conditions, Steta
(1987) reported that $\mathrm{N}$ levels of 150,300 , and $600 \mathrm{~kg} \cdot \mathrm{ha}^{-1}$ had no significant effect on the percentage of broccoli buds showing brown bead. Low $\mathrm{Ca}$ levels associated with rapid growth were thought to be related to brown bead (Flint, 1985), although this relationship was not clearly demonstrated (Steta, 1987). In contrast, Pascual et al. (1996) reported that broccoli heads with brown bead had higher $\mathrm{Ca}$ content and lower $\mathrm{K}$ than healthy ones.

Broccoli grows best in the temperature range of 16 to $18^{\circ} \mathrm{C}$, with a minimum of $4{ }^{\circ} \mathrm{C}$ and a maximum of $24{ }^{\circ} \mathrm{C}$ (Maynard and Hochmuth, 1997). High temperature has often been associated with the appearance of brown bead. In a controlled environment, temperatures above $30^{\circ} \mathrm{C}$ have induced a greater percentage of heads with brown bead than under temperatures in the range of 15 to $25^{\circ} \mathrm{C}$ (Steta, 1987). In another study, the incidence of brown bead increased exponentially with increasing maximum temperature ( 22 to 38 ${ }^{\circ} \mathrm{C}$ ) during the 5-d period preceding head maturity (Lopez-Galarza et al., 1993). Steta (1987) observed that high relative humidity $(90 \%)$ reduced brown bead incidence, even under high temperature $\left(35^{\circ} \mathrm{C}\right)$. Brown bead may also be related to the presence of ethylene, involved in abscission and senescence induction in various fruits and vegetables (Sexton et al., 1985). Plants treated with ethephon had $66 \%$ of the heads with brown bead, a significantly higher value compared with $0.3 \%$ for nontreated plants (Steta, 1987).

The objectives of this study were to investigate, under field conditions, the relationships between the incidence and severity of brown bead, and variables characterizing the development rate, climate, and mineral nutrition of broccoli heads.

\section{Materials and Methods}

We refer to Jenni et al. (2001) for a complete description of the field layout, planting dates, and soil condition. In this 3-year study, data were collected for 50 variables (Table 1) from 328 plots (41 experimental fields $\times 4 \mathrm{~N}$ fertilization levels $\times 2$ blocks). Plant density was calculated in each plot by counting the number of broccoli plants in two beds containing two rows over a 4-m distance. The incidence of brown bead was expressed as the percentage of plants presenting the symptoms (BBP, in \%). A brown bead index (BBI, from $0=$ no symptoms to $8=$ very severe symptoms) expressed the severity of the symptoms and was evaluated on each head at commercial maturity according to Jenni et al. (2001). Button stage was defined as the time when $50 \%$ of the heads were $2.5 \mathrm{~cm}$ or more in diameter, and commercial maturity as the time when at least $50 \%$ of the heads reached $10 \mathrm{~cm}$ in diameter.

Tissue and soil analyses. When broccoli plants reached the button stage in an experimental field, leaves were randomly sampled from each plot before 10:00 Am and two drops of sap were extracted from the ribs (Hochmuth, 1994). Three measurements of tissue $\mathrm{NO}_{3}-\mathrm{N}$ were made using a Nitrachek kit (Geneq, Montréal). Tissue analysis was performed on 
a sample of four broccoli heads randomly harvested at commercial maturity from the two central beds of each plot. Head florets were cut at $0.5 \mathrm{~cm}$ and dried at $21^{\circ} \mathrm{C}$ for $48 \mathrm{~h}$. Determination of $\mathrm{P}, \mathrm{K}, \mathrm{Ca}, \mathrm{Mg}, \mathrm{B}, \mathrm{Cu}, \mathrm{Fe}$, and $\mathrm{Mn}$ in head tissue was performed by inductively coupled plasma optical emission spectrometry (ICP-OES), and determination of $\mathrm{N}$ was made by segmented-flow analysis (SFA) using Isaac-type digestion (Isaac and Johnson, 1976). Sulfur and molybdenum were measured by ICP-OES in a nitric acid digestion for S (Havlin and Soltampour, 1980) and after dry ashing for Mo (Gupta, 1998). For soil analysis purposes, four subsamples of soil were randomly taken from each plot in each experimental field. The four subsamples were homogenized to constitute one soil sample on which $\mathrm{pH}$ and organic matter were determined (McKeague, 1978). Phosphorus, K, Ca, Mg, $\mathrm{B}, \mathrm{Cu}, \mathrm{Fe}$, and $\mathrm{Mn}$ were determined in these soil samples by ICP-OES using Mehlich 3 extraction (Mehlich, 1984), whereas nitrate content was measured by SFA using 2 м potassium chloride extraction (Bran Luebbe Analyzing Technologies, 1989).

Meteorological data. ACR-10X datalogger (Campbell Scientific, Edmonton, Alta.) located on the farm site recorded readings every $10 \mathrm{mn}$, and averaged or totaled the recorded data every hour. The following meteorological variables were recorded: average air temperature $\left({ }^{\circ} \mathrm{C}\right)$ at $1.2 \mathrm{~m}$, average relative humidity (\%, Vaisala $50 \mathrm{Y}$ temperature and relative humidity probe), total solar radiation $\left(\mathrm{kJ} \cdot \mathrm{m}^{-2}\right.$, LI-COR Silicon Pyranometer), total rain ( $\mathrm{mm}$, Texas Electronics Tipping Bucket Rain Gauge), and average wind speed $\left(\mathrm{m} \cdot \mathrm{s}^{-1}, \mathrm{RM}\right.$ Young Wind Monitor). In addition, two TruChek rain gauges (Geneq) were placed in each experimental field to estimate the cumulative height of irrigation water (mm). For each type of meteorological variable, an average (temperature, relative humidity, wind) or sum (solar radiation, precipitation including irrigation) was calculated over the three following periods: 1 week following the button stage, from the button stage to commercial maturity, and $5 \mathrm{~d}$ preceding commercial maturity.

Development rates. For each experimental field, development rates were defined as $\left(1 \cdot t^{-1}\right) \times 100$, where $t$ (in days) is the time required to complete a development process from planting or direct seeding to the button stage (TXBU) or to commercial maturity (TXMA).

Statistical analyses. We refer to Jenni et al. (2001) for the preliminary treatment of the data as well as the detection of outliers. Data from the 3 years were combined in order to allow the examination of trends and relationships over the entire range of the environmental variables during the course of the experiment. This was consistent with the random nature of the year factor in the analyses of variance performed by Jenni et al. (2001). To investigate the relationships between the BBP and BBI variables and the other quantitative variables in the data set, Spearman's rankbased correlation coefficients were analyzed using SAS procedure CORR (SAS Institute,

Table 1. Codes for variables.

\begin{tabular}{|c|c|c|}
\hline$\overline{\text { Code }}$ & Variables & Units \\
\hline DENS & Population density & No.plants $/ \mathrm{m}^{2}$ \\
\hline TXBU & Development rate from seeding or planting to the button & $\mathrm{d}^{-1}$ \\
\hline TXMA & Development rate from seeding or planting to maturity & $d^{-1}$ \\
\hline NCKB & $\mathrm{N}$ leaf sap content at the button stage & ppm \\
\hline PTIS & Head tissue $\mathrm{P}$ content at maturity & $\%$ \\
\hline KTIS & Head tissue $\mathrm{K}$ content at maturity & $\mathrm{mg} \cdot \mathrm{kg}^{-1}$ \\
\hline CATIS & Head tissue $\mathrm{Ca}$ content at maturity & $\mathrm{mg} \cdot \mathrm{kg}^{-1}$ \\
\hline MGTIS & Head tissue $\mathrm{Mg}$ content at maturity & $\mathrm{mg} \cdot \mathrm{kg}^{-1}$ \\
\hline BTIS & Head tissue B content at maturity & $\mathrm{mg} \cdot \mathrm{kg}^{-1}$ \\
\hline CUTIS & Head tissue $\mathrm{Cu}$ content at maturity & $\mathrm{mg} \cdot \mathrm{kg}^{-1}$ \\
\hline FETIS & Head tissue $\mathrm{Fe}$ content at maturity & $\mathrm{mg} \cdot \mathrm{kg}^{-1}$ \\
\hline MNTIS & Head tissue Mn content at maturity & $\mathrm{mg} \cdot \mathrm{kg}^{-1}$ \\
\hline MOTIS & Head tissue Mo content at maturity & $\mathrm{mg} \cdot \mathrm{kg}^{-1}$ \\
\hline STIS & Head tissue $\mathrm{S}$ content at maturity & $\mathrm{mg} \cdot \mathrm{kg}^{-1}$ \\
\hline NSOILB & Soil $\mathrm{N}$ at button stage & $\mathrm{mg} \cdot \mathrm{kg}^{-1}$ \\
\hline PHMA & Soil water $\mathrm{pH}$ at broccoli maturity & --- \\
\hline OMMA & Soil organic matter content at broccoli maturity & $\%$ \\
\hline PSOIL & Soil P at broccoli maturity & $\mathrm{mg} \cdot \mathrm{kg}^{-1}$ \\
\hline KSOIL & Soil $\mathrm{K}$ at broccoli maturity & $\mathrm{mg} \cdot \mathrm{kg}^{-1}$ \\
\hline CASOIL & Soil Ca at broccoli maturity & $\mathrm{mg} \cdot \mathrm{kg}^{-1}$ \\
\hline MGSOIL & Soil $\mathrm{Mg}$ at broccoli maturity & $\mathrm{mg} \cdot \mathrm{kg}^{-1}$ \\
\hline BSOIL & Soil B at broccoli maturity & $\mathrm{mg} \cdot \mathrm{kg}^{-1}$ \\
\hline CUSOIL & Soil $\mathrm{Cu}$ at broccoli maturity & $\mathrm{mg} \cdot \mathrm{kg}^{-1}$ \\
\hline FESOIL & Soil Fe at broccoli maturity & $\mathrm{mg} \cdot \mathrm{kg}^{-1}$ \\
\hline MNSOIL & Soil Mn at broccoli maturity & $\mathrm{mg} \cdot \mathrm{kg}^{-1}$ \\
\hline NSOILM & Soil $\mathrm{N}$ at broccoli maturity & $\mathrm{mg} \cdot \mathrm{kg}^{-1}$ \\
\hline MINBU & Average minimum temperature during 1 week after button stage & ${ }^{\circ} \mathrm{C}$ \\
\hline MINBM & Average minimum temperature from button stage to maturity & ${ }^{\circ} \mathrm{C}$ \\
\hline MINMA & Average minimum temperature during $5 \mathrm{~d}$ before maturity & ${ }^{\circ} \mathrm{C}$ \\
\hline MAXBU & Average maximum temperature during 1 week after button stage & ${ }^{\circ} \mathrm{C}$ \\
\hline MAXBM & Average maximum temperature from button stage to maturity & ${ }^{\circ} \mathrm{C}$ \\
\hline MAXMA & Average maximum temperature during $5 \mathrm{~d}$ before maturity & ${ }^{\circ} \mathrm{C}$ \\
\hline RIBU & Rain and irrigation during 1 week after button stage & $\mathrm{mm}$ \\
\hline RIBM & Rain and irrigation from button stage to maturity & $\mathrm{mm}$ \\
\hline RIMA & Rain and irrigation during $5 \mathrm{~d}$ before maturity & $\mathrm{mm}$ \\
\hline RADBU & Solar radiation during 1 week after button stage & $\mathrm{kJ} \cdot \mathrm{m}^{-2}$ \\
\hline RADBM & Solar radiation from button stage to maturity & $\mathrm{kJ} \cdot \mathrm{m}^{-2}$ \\
\hline RADMA & Solar radiation during $5 \mathrm{~d}$ before maturity & $\mathrm{kJ} \cdot \mathrm{m}^{-2}$ \\
\hline RHBU & Average relative humidity during 1 week after button stage & $\%$ \\
\hline RHBM & Average relative humidity from button stage to maturity & $\%$ \\
\hline RHMA & Average relative humidity during $5 \mathrm{~d}$ before maturity & $\%$ \\
\hline WBU & Average wind speed during 1 week after button stage & $\mathrm{m} \cdot \mathrm{s}^{-1}$ \\
\hline WBM & Average wind speed from button stage to maturity & $\mathrm{m} \cdot \mathrm{s}^{-1}$ \\
\hline WMA & Average wind speed during $5 \mathrm{~d}$ before maturity & $\mathrm{m} \cdot \mathrm{s}^{-1}$ \\
\hline BBP & Percentage of heads with brown bead & $\%$ \\
\hline BBI & Index of severity on heads showing brown bead symptoms & $0-8$ \\
\hline KRTIS & $\mathrm{K}:(\mathrm{Ca}+\mathrm{Mg})$ ratio (head tissues) & --- \\
\hline KRSOIL & $\mathrm{K}:(\mathrm{Ca}+\mathrm{Mg})$ ratio (soil) & --- \\
\hline CARTIS & $\mathrm{Ca}:(\mathrm{K}+\mathrm{Mg})$ ratio (head tissues) & --- \\
\hline CARSOIL & $\mathrm{Ca}:(\mathrm{K}+\mathrm{Mg})$ ratio (soil) & --- \\
\hline
\end{tabular}

1997). Multiple-regression models for the prediction of the BBP and BBI variables were generated using the stepwise selection of variables in the SAS procedure REG (SAS Institute, 1997). The significance level for a regressor to remain in the model was set at 0.1 .

\section{Results}

Spearman's rank-based correlation analysis. Many correlation coefficients between the variables of incidence (BBP) and severity (BBI), and the quantitative variables characterizing climate and nutrients in soil and tissue of broccoli heads were of different sign and magnitude for seeded and transplanted broccoli plants and for the $\mathrm{N}$ fertilization levels considered separately (Tables 2 and 3). Therefore, seeded and transplanted broccoli plants did not appear to respond similarly to their environment regarding brown bead.
Variables expressing incidence and severity of brown bead in transplanted broccoli plants were often correlated with meteorological variables (Tables 2 and 3). Brown bead incidence and severity decreased in transplanted plants as minimum and maximum temperature increased. With all fertilization levels considered together, BBP was negatively correlated with MINBU $\left(\mathrm{r}=-0.300^{* *}\right)$, MINBM $\left(\mathrm{r}=-0.334^{* *}\right)$, and MAXBU $\left(\mathrm{r}=-0.528^{* *}\right)$, and BBI was negatively correlated with MINMA $\left(\mathrm{r}=-0.346^{* *}\right), \operatorname{MAXBM}\left(\mathrm{r}=-0.291^{* *}\right)$, and $\operatorname{MAXMA}\left(\mathrm{r}=-0.392^{* *}\right)$.

For all $\mathrm{N}$ fertilization levels considered together, the percentage of heads with brown bead symptoms was often negatively correlated with the amounts of water supplied to the plots, particularly during periods close to maturity $\left(r=-0.313^{* *}\right.$ for the direct-seeded plants and $r=-0.414^{* *}$ for the transplants; Table 2). The severity index increased as wa- 
Table 2. Spearman rank-based correlations between the percentage of broccoli heads with brown bead symptoms and quantitative variables related to climate and nutrient content of soil and tissue for seeded vs. transplanted broccoli, the four levels of $\mathrm{N}$ fertilization considered separately and all together ${ }^{2}$.

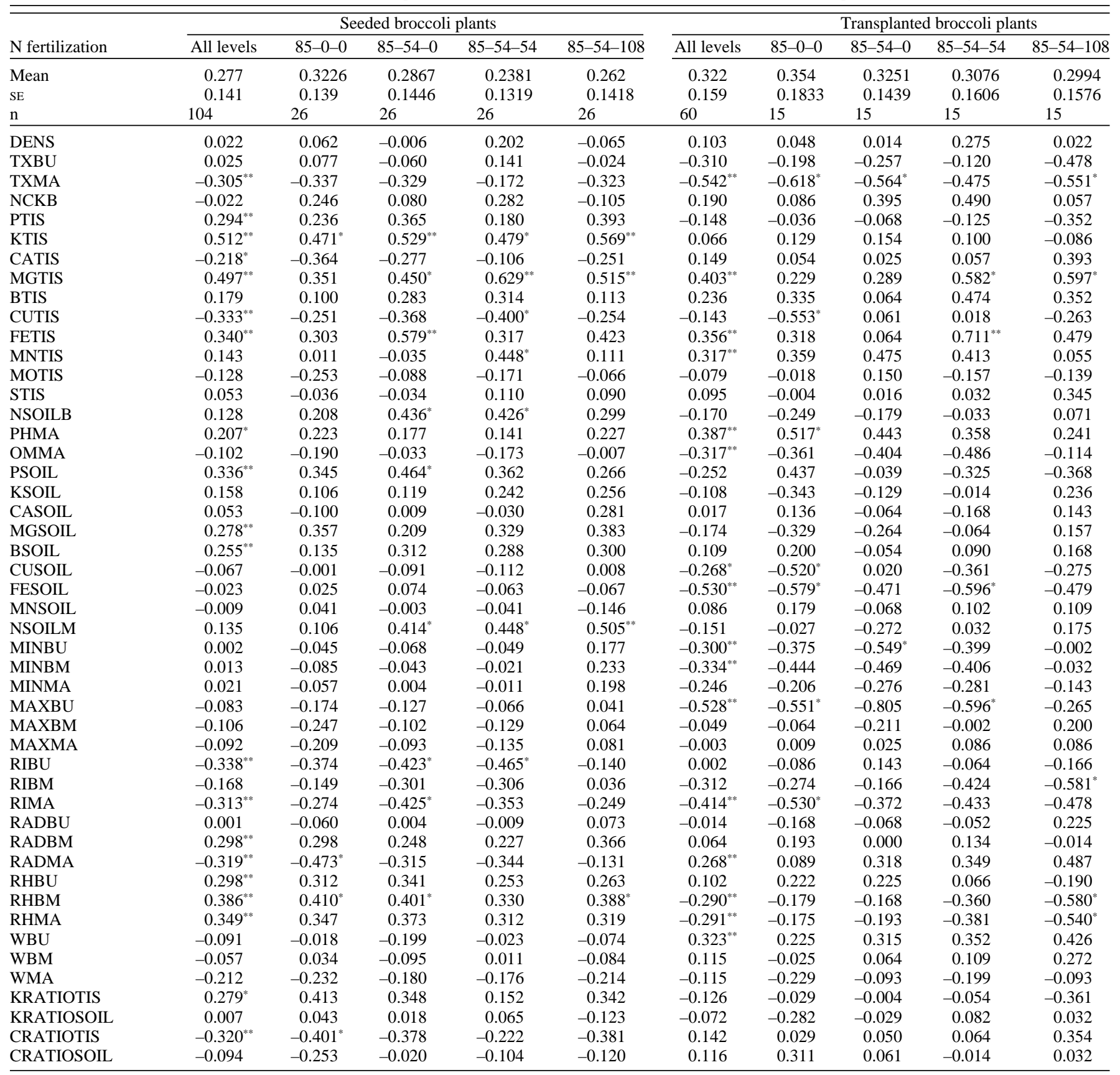

**** Significant at $P \leq 0.05$ or 0.01 , respectively.

ter supply decreased in the direct-seeded plots that received high levels of $\mathrm{N}$ (i.e., 85-54-104, $\left.r=-489^{*}\right)$. Therefore, a regular supply of water appeared to be an important factor to decrease the incidence and severity of brown bead.

For seeded broccoli plants, BBP and BBI tended to be positively correlated with tissue $\mathrm{K}, \mathrm{Mg}$, and Fe concentrations in the head and negatively correlated with tissue $\mathrm{Ca}$ and $\mathrm{Cu}$ concentrations (Tables 2 and 3). BBI tended to be negatively correlated with tissue Mo concentration.

Stepwise multiple regression. Regression models predicting the percentage of heads with brown bead symptoms were different for the direct-seeded and the transplanted broccoli plants (Tables 4 and 5). The variables selected also differed among the models developed at each level of $\mathrm{N}$ fertilization. For all $\mathrm{N}$ fertilization levels considered together, $76 \%$ of the variation in the percentage of heads with brown bead symptoms was explained by 11 variables for direct-seeded broccoli plants $(\mathrm{n}=$ 104 ), and $69 \%$ by five variables for transplanted broccoli plants $(n=44)$.

The Mg concentration in the tissue of heads at maturity was an important variable closely related to both BBP and BBI for direct-seeded broccoli plants. For these plants, solar radiation between the button stage and maturity was important in predicting BBP as that climatic variable entered as first or second regressor in the models (Table 4). More solar radiation during this period, which probably induced an increased transpiration, meant more heads with brown bead. The amounts of rain and irrigation water were also important in predicting BBP for direct-seeded broccoli, a greater supply of water resulting in fewer heads with brown bead.

For transplanted broccoli plants, minimum air temperature at time close to maturity was a key variable to predict $\mathrm{BBP}$, that climatic variable being selected twice as the first regressor to enter the model (Table 4). The average minimum temperature between the button stage and maturity represented $49 \%$ of the variation of the BBP variable at the 85-54$0 \mathrm{~N}$ fertilization level, and $43 \%$ at the $85-54$ $54 \mathrm{~N}$ fertilization level. Otherwise, the variables associated with maximum air tempera- 
Table 3. Spearman rank-based correlations between the index of brown bead severity and quantitative variables related to climate and nutrient content of soil and tissue for seeded vs. transplanted broccoli, the four levels of $\mathrm{N}$ fertilization considered separately and all together ${ }^{\mathrm{Z}}$.

\begin{tabular}{|c|c|c|c|c|c|c|c|c|c|c|}
\hline \multirow[b]{2}{*}{$\mathrm{N}$ fertilization } & \multicolumn{5}{|c|}{ Seeded broccoli plants } & \multicolumn{5}{|c|}{ Transplanted broccoli plants } \\
\hline & All levels & $85-0-0$ & $85-54-0$ & $85-54-54$ & $85-54-108$ & All levels & $85-0-0$ & $85-54-0$ & $85-54-54$ & $85-54-108$ \\
\hline Mean & 3.281 & 3.667 & 3.349 & 3.123 & 2.985 & 3.944 & 4.187 & 3.908 & 3.836 & 3.845 \\
\hline SE & 1.348 & 1.169 & 1.196 & 1.575 & 1.391 & 1.429 & 1.816 & 1.047 & 1.515 & 1.353 \\
\hline $\mathrm{n}$ & 104 & 26 & 26 & 26 & 26 & 60 & 15 & 15 & 15 & 15 \\
\hline DENS & -0.043 & -0.0732 & -0.1789 & 0.1785 & -0.031 & $0.316^{* *}$ & -0.1038 & 0.4129 & 0.2964 & $0.7276^{* *}$ \\
\hline TXBU & 0.158 & 0.0752 & 0.3216 & 0.1519 & 0.0842 & -0.158 & -0.0335 & 0.0475 & -0.1844 & -0.461 \\
\hline TXMA & -0.031 & -0.1849 & -0.0506 & 0.1351 & -0.0381 & 0.148 & 0.3261 & 0.0688 & 0.3642 & -0.096 \\
\hline NCKB & 0.027 & 0.2161 & 0.04 & 0.2048 & 0.1474 & -0.024 & 0.2357 & 0.1644 & 0.2288 & $-0.5786^{*}$ \\
\hline PTIS & 0.029 & -0.13 & 0.0371 & -0.0722 & 0.2412 & $0.334^{* *}$ & 0.2929 & 0.4767 & 0.2395 & 0.2377 \\
\hline KTIS & $0.276^{* * *}$ & 0.1402 & 0.3154 & 0.1436 & $0.422^{*}$ & $0.259^{*}$ & 0.4893 & 0.2464 & 0.0089 & 0.0179 \\
\hline CATIS & 0.076 & -0.0988 & 0.1633 & 0.1026 & 0.0127 & $-0.263^{*}$ & -0.3679 & -0.4857 & -0.1805 & 0.0107 \\
\hline MGTIS & $0.468^{* *}$ & 0.2774 & 0.349 & $0.5412^{* * *}$ & $0.6115^{* *}$ & $-0.255^{*}$ & -0.0964 & $-0.6107^{*}$ & -0.4429 & 0.0143 \\
\hline BTIS & 0.141 & -0.0137 & 0.0802 & 0.2474 & 0.2862 & $-0.348^{* *}$ & -0.1377 & $-0.7979^{* * *}$ & -0.3166 & -0.288 \\
\hline CUTIS & $-0.416^{* *}$ & $-0.4512^{*}$ & -0.3681 & -0.2709 & $-0.5314^{* *}$ & -0.126 & -0.2952 & 0.2931 & -0.4429 & -0.2075 \\
\hline FETIS & $0.352^{* *}$ & 0.2878 & 0.2777 & $0.5251^{* * *}$ & $0.4944^{*}$ & 0.005 & 0.2357 & -0.1821 & -0.0464 & -0.2679 \\
\hline MNTIS & -0.115 & -0.2659 & -0.1738 & 0.0003 & -0.0553 & -0.077 & -0.2181 & -0.0161 & 0.0197 & -0.0679 \\
\hline MOTIS & $-0.37^{* *}$ & $-0.4363^{*}$ & $-0.6389^{* *}$ & -0.3292 & -0.2809 & -0.083 & -0.3714 & 0.2214 & -0.2571 & 0.0786 \\
\hline STIS & $0.283^{* *}$ & 0.0441 & 0.3629 & 0.3847 & 0.2387 & $-0.275^{* *}$ & -0.3378 & -0.4593 & -0.3643 & 0.0894 \\
\hline NSOILB & 0.006 & 0.0747 & 0.2153 & 0.1853 & 0.1102 & -0.083 & -0.2909 & -0.0468 & 0.3879 & 0.0385 \\
\hline PHMA & $-0.196^{*}$ & -0.0787 & -0.3607 & -0.3217 & -0.0602 & 0.002 & -0.195 & 0.2786 & -0.168 & 0.1752 \\
\hline OMMA & 0.093 & 0.0537 & 0.305 & 0.048 & 0.1231 & 0.13 & 0.1393 & -0.078 & 0.1 & 0.25 \\
\hline PSOIL & $0.225^{*}$ & $0.4152^{*}$ & -0.0646 & 0.2319 & 0.3516 & $0.338^{* *}$ & 0.4122 & 0.1541 & 0.3071 & 0.3286 \\
\hline KSOIL & $0.373^{* *}$ & 0.3467 & $0.5284^{* *}$ & 0.3101 & 0.381 & -0.036 & 0.2714 & -0.4607 & -0.3786 & 0.1929 \\
\hline CASOIL & -0.057 & -0.107 & 0.0219 & -0.1056 & -0.0301 & $0.388^{* * *}$ & 0.1714 & $0.7357^{* *}$ & 0.1786 & $0.5393^{*}$ \\
\hline MGSOIL & $0.334^{* *}$ & 0.3235 & 0.3842 & $0.4564^{*}$ & 0.2482 & -0.084 & 0.1893 & $-0.55^{*}$ & -0.0036 & -0.0071 \\
\hline BSOIL & 0.157 & 0.0133 & 0.205 & 0.0425 & $0.4207^{*}$ & 0.109 & 0.1216 & 0.265 & -0.0609 & 0.2433 \\
\hline CUSOIL & $-0.227^{*}$ & -0.1197 & -0.2962 & $-0.416^{*}$ & -0.0421 & $0.272^{*}$ & 0.2484 & 0.4879 & 0.3821 & 0.1376 \\
\hline FESOIL & 0.028 & 0.0486 & 0.125 & 0.0899 & -0.0995 & 0.01 & 0.1786 & -0.2179 & -0.1321 & 0.1179 \\
\hline MNSOIL & $-0.243^{*}$ & -0.0732 & -0.3434 & -0.3338 & -0.3345 & 0.178 & 0.0464 & 0.0714 & 0.0643 & 0.3646 \\
\hline NSOILM & 0.112 & 0.0103 & 0.3062 & $0.4923^{*}$ & $0.4114^{*}$ & -0.132 & -0.2914 & -0.2724 & 0.2429 & -0.0143 \\
\hline MINBU & 0.066 & -0.0024 & 0.0975 & 0.261 & -0.0518 & -0.089 & -0.0521 & -0.2119 & -0.2621 & 0.1239 \\
\hline MINBM & 0.001 & -0.0896 & 0.0356 & 0.1515 & -0.0262 & -0.231 & -0.3327 & -0.2916 & -0.3936 & 0.1055 \\
\hline MINMA & -0.054 & -0.0448 & -0.0577 & 0.0065 & -0.0645 & $-0.346^{* *}$ & -0.4996 & -0.2489 & $-0.5228^{*}$ & -0.1468 \\
\hline MAXBU & 0.064 & -0.0301 & 0.0171 & 0.312 & -0.0154 & -0.022 & 0.186 & -0.1914 & -0.161 & 0.0125 \\
\hline MAXBM & 0.027 & -0.0763 & 0.0171 & 0.2405 & -0.0284 & $-0.291^{* *}$ & -0.1503 & $-0.5528^{*}$ & $-0.5152^{*}$ & -0.0912 \\
\hline MAXMA & -0.015 & -0.0951 & 0.0132 & 0.0923 & -0.0308 & $-0.392^{* *}$ & -0.3115 & $-0.6016^{*}$ & $-0.5891^{*}$ & -0.1987 \\
\hline RIBU & $-0.242^{*}$ & -0.3711 & -0.1213 & -0.2743 & -0.1593 & 0.025 & -0.3023 & 0.1932 & 0.1342 & 0.0894 \\
\hline RIBM & -0.17 & -0.198 & 0.0308 & -0.2476 & -0.2062 & 0.22 & -0.0483 & $0.5523^{*}$ & 0.3378 & 0.109 \\
\hline RIMA & $-0.233^{*}$ & -0.0718 & -0.1026 & -0.2284 & $-0.4884^{*}$ & 0.113 & -0.1038 & 0.4633 & 0.1288 & 0.0644 \\
\hline RADBU & 0.071 & 0.1347 & -0.0759 & 0.1173 & 0.1172 & -0.196 & -0.3327 & -0.2451 & -0.2039 & 0.1055 \\
\hline RADBM & $0.223^{*}$ & 0.2738 & 0.3423 & 0.1097 & 0.2038 & 0.205 & $0.6225^{*}$ & -0.0411 & 0.1753 & -0.0948 \\
\hline RADMA & -0.181 & -0.319 & -0.1429 & -0.0058 & -0.2141 & -0.125 & -0.0894 & -0.3309 & -0.2755 & 0.195 \\
\hline RHBU & 0.044 & 0.1216 & -0.0144 & -0.0527 & 0.0976 & 0.217 & 0.1395 & 0.288 & 0.3256 & 0.0268 \\
\hline RHBM & -0.031 & 0.0082 & -0.1132 & -0.1228 & 0.0869 & 0.19 & 0.0286 & 0.3882 & 0.3578 & 0.0304 \\
\hline RHMA & -0.05 & -0.0267 & -0.1026 & -0.1217 & 0.0588 & -0.046 & -0.4329 & 0.3846 & 0.0894 & -0.1127 \\
\hline WBU & -0.083 & -0.0113 & -0.1399 & -0.2533 & 0.0955 & $-0.355^{* *}$ & -0.3435 & $-0.517^{*}$ & -0.3757 & -0.1449 \\
\hline WBM & -0.015 & 0.0482 & 0.0763 & -0.1577 & 0.0038 & $-0.266^{*}$ & -0.3005 & -0.4347 & -0.161 & -0.0662 \\
\hline WMA & -0.144 & -0.0684 & -0.0404 & -0.2387 & -0.1936 & 0.252 & 0.0842 & 0.3241 & $0.5336^{*}$ & 0.1952 \\
\hline KRATIOTIS & -0.043 & 0.0653 & -0.0506 & -0.1179 & 0.0315 & $0.284^{* *}$ & 0.4286 & 0.4929 & 0.1429 & 0.0179 \\
\hline KRATIOSOIL & $0.274^{* *}$ & 0.2595 & 0.3139 & 0.2615 & 0.2031 & $-0.266^{*}$ & 0.0893 & $-0.7286^{* *}$ & -0.425 & -0.1036 \\
\hline CRATIOTIS & -0.003 & -0.082 & -0.011 & 0.050 & -0.073 & $-0.269^{*}$ & -0.429 & -0.493 & -0.146 & 0.018 \\
\hline CRATIOSOIL & $-0.283^{* *}$ & -0.229 & -0.357 & $-0.416^{* *}$ & -0.215 & 0.229 & -0.129 & 0.754 & 0.021 & 0.329 \\
\hline
\end{tabular}

*,** Significant at $P \leq 0.05$ or 0.01 , respectively.

ture did not appear in the models predicting BBP. Soil Ca was important in predicting BBP and BBI. That soil nutritional variable entered in the third position when all $\mathrm{N}$ fertilization levels were considered together, and in the first position at the 85-0-0 level for predicting BBP. Further, the soil Ca variable entered in the second position when all $\mathrm{N}$ fertilization levels were considered together and in the first position at the 85-54-108 level for predicting BBI (Tables 4 and 5).

Variables that did not intervene in any model included: $\mathrm{Mn}$ in broccoli head tissues (direct-seeded and transplanted plants) and soil (transplanted plant), soil K (direct-seeded or transplanted plants), and soil Fe (directseeded plants).

\section{Discussion}

Transplanted and direct-seeded broccoli plants did not respond in the same way to their surrounding environment with regards to brown bead. Seedlings growing in the restricted area of a multicell have an underdeveloped root system that tends to grow more in the upper horizons of the field soil. Transplanted plants are more sensitive to soil conditions in the plow layer $(0-30 \mathrm{~cm})$ than direct-seeded plants, which are more likely to exploit deeper soil horizons (30-60 cm) (NeSmith, 1999). Therefore, it is not surprising that field conditions promoting the fast development of a transplanted broccoli crop, which has to recover from the transplanting shock, would tend to produce less brown bead. In contrast, high air temperature and fast development have often been associated with high incidence of brown bead (Hildebrand, 1994; Steta, 1987). In protected conditions, the average maximum temperature during the $5 \mathrm{~d}$ preceding commercial maturity was found to be highly correlated with the percentage of broccoli heads with brown bead (Lopez-Galarza et al., 1993). For instance, $10 \%$ of the heads had brown bead at $30^{\circ} \mathrm{C}$ compared with $50 \%$ at 36 ${ }^{\circ} \mathrm{C}$. In our study, the transplanted broccoli plants were produced early in the season and harvested before the warmest periods of the summer. We found a negative correlation between the development rate to commercial maturity and the percentage of heads with brown bead 
Table 4. Stepwise multiple regressions in which the percentage of heads with brown bead symptoms is explained by climatic and nutritional variables for seeded vs. transplanted broccoli plants, the four levels of $\mathrm{N}$ fertilization considered separately and all together.

\begin{tabular}{|c|c|c|c|c|c|c|c|c|c|c|}
\hline \multirow[b]{2}{*}{ Variables } & \multicolumn{2}{|c|}{ All $\mathrm{N}$ fertilization levels } & \multicolumn{2}{|l|}{$85-0-0$} & \multicolumn{2}{|c|}{$85-54-0$} & \multicolumn{2}{|l|}{$85-54-54$} & \multicolumn{2}{|c|}{$85-54-108$} \\
\hline & Estimate & $\operatorname{Order}^{2}$ & Estimate & Order & Estimate & Order & Estimate & Order & Estimate & Order \\
\hline \multicolumn{11}{|c|}{ Seeded broccoli plants } \\
\hline INTERCEPT & $-2.189^{* * *}$ & & $0.7961^{+}$ & & $-0.6212^{*}$ & & $-0.9252^{*}$ & & $-2.965^{* * *}$ & \\
\hline TXMA & & & & & & & & & $-0.7071^{* * *}$ & 4 \\
\hline NCKB & $-0.0003022^{* *}$ & 9 & & & & & & & & \\
\hline KTIS & & & $0.00001772^{*}$ & 5 & $0.00003239^{* *}$ & 1 & & & $0.00000766^{* *}$ & 10 \\
\hline CATIS & & & & & & & & & $0.00002374^{* * * *}$ & 6 \\
\hline FETIS & & & & & & & & & $0.0008296^{* *}$ & 12 \\
\hline MOMA & & & $-0.04452^{*}$ & 4 & & & & & & \\
\hline PSOIL & $0.001080^{+}$ & 12 & & & & & & & & \\
\hline MGSOIL & $0.0003418^{* * *}$ & 7 & & & & & $0.0002476^{* *}$ & 5 & $0.0006515^{* * *}$ & 1 \\
\hline BSOIL & & & & & & & $0.1226^{* * *}$ & 4 & & \\
\hline CUSOIL & & & & & & & $-0.04801^{*}$ & 6 & & \\
\hline RIMA & $0.001149^{*}$ & 11 & & & & & & & $0.001129^{* * * *}$ & 9 \\
\hline RADBM & $0.00000663^{* * *}$ & 1 & $0.00001068^{* * *}$ & 2 & $0.00000585^{*}$ & 2 & & & & \\
\hline RADMA & $-0.00000895^{+}$ & 3 & $-0.00002313^{*}$ & 1 & & & $-0.00001835^{* *}$ & 3 & & \\
\hline RHBU & $0.015292^{* * *}$ & 8 & & & & & & & & \\
\hline RHBM & & & & & & & $0.008142^{+}$ & 7 & $0.03565^{* * *}$ & 2 \\
\hline RHMA & $0.016115^{* * *}$ & 6 & & & & & & & $0.005912^{* * * *}$ & 5 \\
\hline KRATIOSOIL & & & & & & & $-9.487^{* * *}$ & 2 & $-1.3387^{*}$ & 11 \\
\hline$R^{2}$ & 76.0 & & 74.3 & & 48.0 & & 85.1 & & 99.6 & \\
\hline $\mathrm{n}$ & 104 & & 26 & & 26 & & 26 & & 26 & \\
\hline \multicolumn{11}{|c|}{ Transplanted broccoli plants } \\
\hline INTERCEPT & 0.9355 & & $4.526^{* *}$ & & $1.743^{* *}$ & & $1.764^{*}$ & & $4.504^{* *}$ & \\
\hline TXBU & & & $-0.09219^{* *}$ & 8 & & & & & & \\
\hline TXMA & & & $-1.9610^{* *}$ & 2 & & & & & & \\
\hline RHBU & $0.03768^{* * *}$ & 4 & $0.02056^{* *}$ & 6 & & & & & $0.02670^{* *}$ & 5 \\
\hline RHBM & $-0.04444^{* * *}$ & 2 & $-0.03366^{* *}$ & 4 & & & & & & \\
\hline RHMA & & & & & & & & & $-0.0672^{* *}$ & 1 \\
\hline WBU & & & & & & & & & $0.02343^{* *}$ & 8 \\
\hline KRATIOTIS & $-0.03404^{*}$ & 5 & & & & & & & $-0.0179^{* *}$ & 6 \\
\hline KRATIOSOIL & & & & & & & & & $-6.701^{* *}$ & 2 \\
\hline$R^{2}$ & 69.2 & & 100.0 & & 48.8 & & 43.2 & & 100.0 & \\
\hline $\mathrm{n}$ & 44 & & 11 & & 11 & & 11 & & 11 & \\
\hline
\end{tabular}

${ }^{2}$ Order of entrance of the variable in the regression model.

${ }^{+, *, * *, * * *}$ Slope estimate in the final regression model is significant at $P \leq 0.1,0.05,0.01$, or 0.001 , respectively.

in the direct-seeded plants $\left(\mathrm{r}=-0.305^{* *}\right)$ and in the transplanted plants $\left(\mathrm{r}=-0.542^{* *}\right)$. Within an optimum temperature range, the development rate usually increases linearly with the average air temperature (Arnold, 1959; Tan et al., 2000). Linear heat unit models have been developed for many crops under this assumption. Therefore, higher, though not extreme, air temperatures favoring the fast development of broccoli may have resulted in a decrease of brown bead incidence. Evidently, maximum temperature during the $5 \mathrm{~d}$ prior to maturity was not of primary importance to predict the percentage of heads with brown bead or the severity of symptoms (Tables 4 and 5).

Whereas meteorological variables were strongly associated with brown bead incidence for transplanted broccoli plants, tissue nutrient content appeared to be more strongly associated with brown bead in the case of direct-seeded broccoli. Calcium and its antagonistic dynamics with $\mathrm{K}$ and $\mathrm{Mg}$ have already been pointed out in the few papers published on brown bead. The physiological disorder was associated with rapid growth and the resulting nutritional imbalance, including Ca deficiency (Steta, 1987). However, Pascual et al. (1996) reported that florets with brown bead had higher $\mathrm{Ca}$ and $\mathrm{Mg}$ content and lower $\mathrm{K}$ content, whereas the $\mathrm{K}:(\mathrm{Ca}+\mathrm{Mg})$ ratio was higher in healthy florets. In our study, there was no evidence of a relationship between the $\mathrm{K}:(\mathrm{Ca}+\mathrm{Mg})$ ratio and the variables character- izing brown bead. Furthermore, low levels of $\mathrm{Ca}$ and high levels of $\mathrm{K}$ and $\mathrm{Mg}$ in the head tissues at maturity resulted in a high incidence and severity of brown bead in direct-seeded broccoli plants. These results confirm those of Steta (1987), who associated the incidence of brown bead with low levels of $\mathrm{Ca}$ in the plant and, to some extent, those of Maroto et al (1993), who reported that foliar applications of calcium chloride decreased brown bead incidence in some cases.

Developing reproductive tissues, or vegetative tissues enclosed around older leaves, are disadvantaged in the allocation of $\mathrm{Ca}$ in plants (Barta and Tibbitts, 2000). Most Cainduced disorders are caused by a general disintegration of membrane structures, with 
Table 5. Stepwise multiple regressions in which the index of brown bead severity is explained by climatic and nutritional variables for seeded vs. transplanted broccoli plants, the four levels of $\mathrm{N}$ fertilization considered separately and all together.

\begin{tabular}{|c|c|c|c|c|c|c|c|c|c|c|}
\hline \multirow[b]{2}{*}{ Variables } & \multicolumn{2}{|c|}{ All $\mathrm{N}$ fertilization levels } & \multicolumn{2}{|c|}{$85-0-0$} & \multicolumn{2}{|c|}{$85-54-0$} & \multicolumn{2}{|c|}{$85-54-54$} & \multicolumn{2}{|c|}{$85-54-108$} \\
\hline & Estimate & Order $^{2}$ & Estimate & Order & Estimate & Order & Estimate & Order & Estimate & Order \\
\hline \multicolumn{11}{|c|}{ Seeded broccoli plants } \\
\hline INTERCEPT & $-2.579^{+}$ & & $4.713^{* * * *}$ & & $3.596^{* *}$ & & 4.925 & & -2.184 & \\
\hline DENS & & & & & & & & & $-0.2841^{*}$ & 2 \\
\hline MGTIS & $0.002288^{* * * *}$ & 1 & & & $-1.876^{* *}$ & 1 & $0.003142^{*}$ & 1 & $0.005109^{* * * *}$ & 1 \\
\hline CUTIS & & & $-0.1079^{*}$ & 1 & & & & & & \\
\hline MOTIS & $-2.083^{* * *}$ & 2 & & & & & & & & \\
\hline PSOIL & $0.01737^{*}$ & 4 & & & & & & & & \\
\hline MGSOIL & & & & & $0.00258^{* *}$ & 2 & $0.00201^{*}$ & 4 & & \\
\hline MNSOIL & & & & & & & $-0.03065^{* *}$ & 3 & & \\
\hline RIBU & & & & & & & $-0.01277^{+}$ & 5 & & \\
\hline RADBU & $0.00015^{* * *}$ & 3 & & & & & & & & \\
\hline WBM & & & & & & & $-4.335^{* * *}$ & 2 & & \\
\hline WMA & & & & & & & & & $-1.058^{+}$ & 3 \\
\hline$R^{2}$ & 36.8 & & 16.0 & & 45.8 & & 71.4 & & 52.9 & \\
\hline n 104 & & & 26 & & 26 & & 26 & & 26 & \\
\hline \multicolumn{11}{|c|}{ Transplanted broccoli plants } \\
\hline INTERCEPT & $6.375^{*}$ & & $26.76^{* * * *}$ & & $10.67^{* *}$ & & $-5.904^{*}$ & & $18.16^{* *}$ & \\
\hline DENS & & & & & & & $1.202^{* *}$ & 1 & & \\
\hline NCKB & & & & & & & & & $-0.003333^{* *}$ & 7 \\
\hline NSOILB & & & & & & & $0.01357^{+}$ & 2 & $-0.008484^{* *}$ & 5 \\
\hline PTIS & & & & & $10.84^{* *}$ & 2 & & & & \\
\hline CUTIS & & & $-0.3383^{* *}$ & 2 & & & & & & \\
\hline FETIS & & & & & $-0.00871^{* *}$ & 4 & & & & \\
\hline STIS & & & & & & & & & $-0.0002343^{* *}$ & 6 \\
\hline PHMA & & & & & & & & & $-5.890^{* *}$ & 4 \\
\hline CASOIL & $0.000508^{+}$ & 2 & & & & & & & $0.004576^{* *}$ & 1 \\
\hline MGSOIL & & & & & & & & & $0.005512^{* *}$ & 2 \\
\hline BSOIL & & & $-2.604^{*}$ & 3 & $-0.05369^{*}$ & 8 & & & & \\
\hline CUSOIL & & & & & & & & & $0.6978^{* *}$ & 3 \\
\hline FESOIL & & & & & $-0.01689^{* *}$ & 1 & & & & \\
\hline MINBM & & & & & $-0.1715^{* *}$ & 6 & & & & \\
\hline MINMA & $-0.3354^{*}$ & 1 & $-0.9761^{* *}$ & 1 & & & & & & \\
\hline RIBM & & & & & $-0.00075^{*}$ & 7 & & & & \\
\hline RIMA & & & & & $0.01080^{* * *}$ & 3 & & & & \\
\hline RHBU & & & & & $0.002192^{+}$ & 9 & & & & \\
\hline RHBM & & & & & & & & & $-0.02566^{* *}$ & 8 \\
\hline RHMA & & & & & $-0.07887^{* *}$ & 5 & & & $0.001168^{*}$ & 9 \\
\hline$R^{2}$ & 27.9 & & 86.2 & & 100 & & 68.1 & & 100 & \\
\hline $\mathrm{n}$ & 44 & & 11 & & 11 & & 11 & & 11 & \\
\hline
\end{tabular}

${ }^{\mathrm{z}}$ Order of entrance of the variable in the regression model.

$+,{ }^{*}, * * * * *$ Slope estimate in the final regression model is significant at $P \leq 0.1,0.05,0.01$, or 0.001 , respectively.

meristematic tissues being affected first (Kirby and Pilbeam, 1984). Calcium is an immobile element recognized to be mainly translocated from roots through the xylem by mass flow (Clarkson, 1984). This mass flow results from transpiration, root pressure, and diurnal changes in water stress (Marschner, 1983). Most of the water flux is channeled to leaves exposed to the sun for transpiration, which contributes to the global cooling of the plant. Developing tissues fed by the phloem are often disadvantaged by this competition from transpiring tissues. Competition between sinks, such as buds, and developing leaves and fruits is high when $\mathrm{Ca}$ in the xylem is low and transpiration is high (Clarkson, 1984). It is then likely that broccoli florets are susceptible to $\mathrm{Ca}$ deficiencies. Futhermore, excessive $\mathrm{K}$ and $\mathrm{Mg}$ are likely to aggravate $\mathrm{Ca}$ deficiencies within the plant metabolism (Cubeta et al., 2000; Jakobsen, 1993; Mengel and Kirby, 1987).

Conditions promoting the fast development of transplanted broccoli, including high spring air temperature and a regular supply of water from the button stage to maturity, tended to decrease brown bead incidence in broccoli.
An adequate supply of $\mathrm{N}$ fertilization in the range of 85-54-54 or 85-54-108, along with moderate applications of $\mathrm{K}$ and $\mathrm{Mg}$, should be considered by the grower to prevent brown bead incidence of broccoli. Whenever the development rate of broccoli is interrupted by various causes, including insufficient $\mathrm{N}$, water, $\mathrm{Ca}$, or unfavorable temperature conditions, brown bead will be more present in the fields. Future studies should verify whether foliar applications of Ca provide another part of the solution. Also, the relationships between flower abortion in broccoli and nutrient limitations, changes in temperature, and plant growth rates could be investigated under controlled conditions.

\section{Literature Cited}

Agriculture and Agri-Food Canada. 1999. 19981999 Canadian vegetable situation and trends. Mkt. and Ind. Serv. Branch. May 2000. http:// www.agr.ca/misb/hort/vegetable_eng.html

Arnold, C.Y. 1959. The determination and significance of the base temperature in a linear heat unit system. Amer. Soc. Hort. Sci. 74:430-445.

Barta, D.J. and T.W. Tibbitts. 2000. Calcium localization and tipburn development in lettuce leaves during early enlargement. J. Amer. Soc. Hort. Sci. 125:294-298.

Bran Luebbe Analyzing Technologies. 1989. Industrial method no. 824-89T; nitrate/nitrite in soil and plant extracts, water and wastewater. Technicon Ind. Systems, Elmsford, N.Y.

Clarkson, D.T. 1984. Calcium transport between tissues and its distribution in the plant. Plant Cell Environ. 7:449-456.

Conseil des Productions Végétales du Québec (CPVQ). 1995. Légumes: Crucifères (chou pommé, brocoli, chou-fleur et choux de Bruxelles). Feuillet technique du Conseil des Prod. Vég. du Québec. Agdex 252.

Cubeta, M.A., B.R. Cody, R.E. Sugg, and C.R. Crozier. 2000. Influence of soil calcium, potassium, and $\mathrm{pH}$ on development of leaf tipburn of cabbage in eastern North Carolina. Commun. Soil Sci. Plant Anal. 31:259-275.

Flint, M.L. 1985. Integrated pest management for cole crops and lettuce. Univ. of California, Statewide Integrated Pest Mgt. Proj., Div. Agr. Natl. Res., Oakland.

Gupta, U.C. 1998. Determination of boron, molybdenum, and selenium in plant tissue, p. 171-182. In: Y.P. Kalra (ed.). Handbook of reference methods for plant analysis. CRC Press, Boca Raton, Fla.

Havlin, J. and P. Soltampour. 1980. A nitric acid plant tissue digest method for use with induc- 
tively coupled plasma spectrometry. Commun. Soil Sci. Plant Anal. 11:969-980.

Hildebrand, P.D. 1994. Non-infectious diseases. In: R.J. Howard, J.A. Garland, and W.L. Seaman (eds.). Diseases and pests of vegetable crops in Canada. Can. Phytopathol. Soc. and Entomol. Soc. Can., Ottawa, Ont.

Hochmuth, G.J. 1994. Efficiency ranges for nitrate-nitrogen and potassium for vegetable petiole sap quick test. HortTechnology 4:218-222.

Isaac, R.A. and W.C. Johnson. 1976. Determination of total nitrogen in plant tissue, using a block digestor. J. AOAC Intl. 59:98-100.

Jakobsen, S. T. 1993. Interaction between plant nutrients. III. Antagonism between potassium, magnesium and calcium. Acta Agr. Scand., Sect. B, Soil Plant Sci. 43:1-5.

Jenni, S., P. Dutilleul, S. Yamasaki, and N. Tremblay. 2001. Brown bead of broccoli. I. Response of the physiological disorder to management practices. HortScience 36:1224-1227.

Kirby, F.A. and D.J. Pilbeam. 1984. Calcium as plant nutrient. Plant Cell Eviron. 7:397-405.

Lopez-Galarza, S., A. San Bautista and J.V. Maroto. 1993. Influencia de la temperatura en la incidencia del desorden de Los Granos Marrones en broculi cv 'Skiff'. Actas II Congr. lberico de Ciencias Hort. 1342-1345.

Maroto, J.V., S. Lopez-Galarza, B. Pascual, J. Alagarda, and M.S. Bono. 1993. Influencia de dos sistemas de manejo forzado y de aplicaciones foliares càlcicas en el compotamiento productivo y la incidencia de la fisiopatatia de los "granos marrones" en los diversos cvs de bròculi. Actas II Congr. lberico de Ciencias Hort. 1336-1341.

Marschner, H. 1983. General introduction to the mineral nutrition of plants, p. 5-60. In: A. Lauchli and R.L. Bielski (eds.). Encyclopedia of plant physiology. Inorganic plant nutrition. vol. 15A. Springer Verlag, New York.

Maynard, D.N. and G.J. Hochmuth. 1997. Knott's handbook for vegetable growers. 4th ed. Wiley, New York.

McKeague, J.A. 1978. Manuel des méthodes d'échantillonage et d'analyse des sols. 2ème édition. Société Can. de la Sci. du Sols. Ottawa, Ont.

Mehlich, A. 1984. Mehlich 3 soil test extractant: A modification of Mehlich 2 extractant. Commu. Soil Sci. Plant Anal. 15:1409-1416.
Mengel, K. and E.A. Kirby. 1987. Principles of plant nutrition. 4th ed. Intl. Potash Inst., Bern, Switzerland.

NeSmith, D.S. 1999. Root distribution and yield of direct seeded and transplanted watermelon. J Amer. Soc. Hort. Sci 124:458-461.

Pascual, B., J.V. Maroto, S. Lopez-Galarza, J. Alagarda, M.S. Bono, and A. San Bautista. 1996. Changes in some nutrient contents of broccoli (Brassica oleracea L. var. italica Plenck) inflorescences affected by the brown bud disorder. Acta Hort. 407:327-332.

SAS Institute. 1997. SAS for Windows, release 6.12. SAS Inst., Cary, N.C.

Sexton, R., L.N. Lewis, A.J. Trewavas, and P. Kelly. 1985. Ethylene and abscission, p. 173-196. In J.A. Roberts and G.A. Tucker (eds.). Ethylene and plant development. Butterworths, Boston.

Steta, M. 1987. Brown bead, a physiological disorder in broccoli (Brassica oleracea L. var italica Plenck). MS Thesis, Univ. of California, Davis.

Tan, D.K.Y, C.J. Birch, A.H. Wearing, and K.G Rickert. 2000. Predicting broccoli development. I. Development is predominantly determined by temperature rather than photoperiod. Scientia Hort. 84:227-243. 